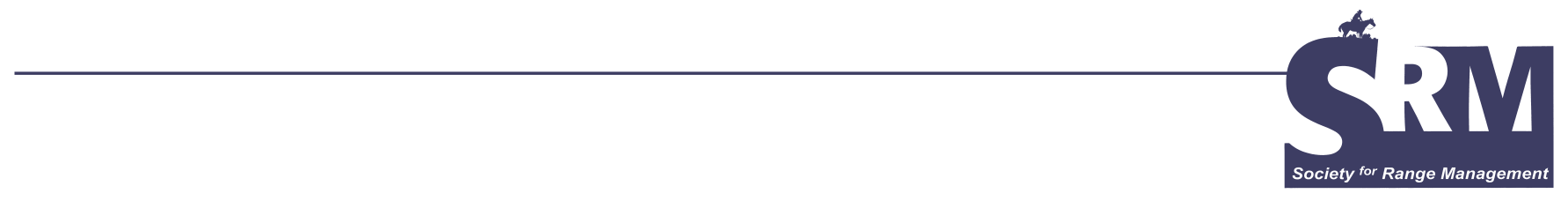

\title{
Tenth in a Series: Insight From SRM's Charter Members
}

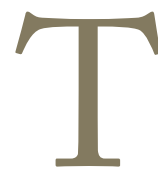
he Society for Range Management (SRM) History Committee has conducted interviews with many of the Society's charter members to capture their perspective of events leading to and subsequent to the formation of the American Society of Range Management in 1947-1948. Interviews from several of these individuals will be shared for today's SRM members to enjoy and learn from.

\section{SRM Charter Member-Charles E. Poulton Editor's Note: Dr Charles E. "Chuck" Poulton, PO Box 2081, Gresham, OR 97030-0601, responded to the interview questions in writing in detail (8 pages). This is a synopsis with emphasis given to Chuck's perspectives of SRM and advice for people enter- ing range and related resource fields.}

Chuck Poulton is an Idaho native. In 1935, he enrolled in Forestry at the University of Idaho but switched to the Range Management option in Forest Management after 1 year. R. J. Beacraft was Professor of Dendrology and advisor for the Range Management option. However, Chuck received his BS in 1939 under Professor Vernon Young. He worked for the US Forest Service before and after military service in the Navy. During the academic year 1946-1947, Chuck started an MS program at Montana State College and taught Harold Heady's range courses while Harold was finishing his $\mathrm{PhD}$ at the University of Nebraska. For the 1947-1948 academic year, Chuck received a teaching assistantship at the University of Idaho as Professor Ed Tisdale's colleague and finished his MS in Range Management and Animal Nutrition. In 1949, Chuck was hired to organize and lead a new bidepartmental program in Range Management at Oregon State University (OSU). His research focused on phytosociology, veg-etation-soil-landform relationships and, from the late 1960s, on remote sensing in resource analysis and monitoring. Chuck continued his graduate work at Washington State University, conducting field research in plant-soil relations in northern Oregon rangeland receiving the $\mathrm{PhD}$ in Plant Ecology and Soils under Rex Daubenmire in Ecology and Henry Smith in Soils.

In 1967-1968, Chuck did 1 year of postdoctoral study and research in remote sensing as part of Dr Bob Colwell's team at the University of California, Berkeley. He continued this emphasis at OSU with National Aeronautics and Space Administration (NASA) funding for several years, organizing and leading the Environmental Remote Sensing Applications Laboratory. After 25 years at OSU, Chuck resigned to become heavily involved in international consulting in a large variety of remote sensing activities, an effort growing out of the NASA Earth Resources program. This work, over several years, led Chuck to work in 18 countries and 5 continents.

\section{From Chuck's Writing:}

I went with Ed Tisdale, new Professor of Range Management at the University of Idaho, to the first organizational meeting for the ASRM. The ad-hoc organizing committee led by Joe Pechanec and Harold Heady laid a wonderful platform from which to move forward. They guided the meeting with superb skill. Discussions were lively, sometimes emotional; but all facets were visited with positive thinking and no private agendas.

My recollection is that the meeting was cosmopolitan with a few wildlife people and ranchers participating. Most participants were federal, with some state agency and university personnel who were involved in rangeland resources research, extension, or management. An excellent foundation was laid for the Society in all its aspects with a committee structure that was very effective. Election of Joe Pechanec as first President could not have been a wiser choice.

Before the meeting, I had strong reservations about further separation among the 3 renewable natural resource pro- 
fessions - forestry, range, and wildlife. Vegetation-landform-soil ecosystems were our common denominator, and I had experienced need for closer collaboration by these 3 professions. Millions of acres of rangeland and wildlife habitat are forested.

I arrived uncertain that a new Society was the way to go. I was a member of the Society of American Foresters, a former Chairman of the Range Management Section of the Society, and had served on a number of Committees within SAF concerned about grazeable resources. The meeting convinced me of the potential for a professional society for range management.

At meeting's end, there was only one thing that caused me concern. It was the Trail Boss symbol. Even being born and growing up on a cattle ranch in southern Idaho and being personally dedicated to keeping the western livestock industry viable as a renewable resource user, I was opposed to casting our new Society in the image of the Trail Boss-great as Charley Russell was as a Western artist and Fred Renner as an expert and proponent of Russell's art.

I spoke my piece and lost. In retrospect, it was okay, but it branded us with the wrong iron and limited the public and lay perception of what SRM stands for and does. When I checked into SRM's first Web page, my concerns were rekindled, and I expressed my concern to the leadership.

On balance, is it time to revisit the question? What logo, if any, would most accurately portray SRM in the 21st century? Do we talk too much to our own pride and Western tradition? To be effective, professionally and politically, in the years ahead, how must we be perceived both within and outside our membership? First impressions still count! The purpose of a logo is to set that first impression, the focal point of recognition!

My initial expectations of ASRM and SRM have reasonably been met; but they aren't being maintained. The Society has had a tremendously beneficial and positive impact on rangeland resources management, education, and practice in North America and, to a commendable extent, in many pastoral regions of the world.

I had high expectations that SRM would be a strong and effective force to improve and maintain acceptable standards of qualification, employment, and performance in our profession. We were very effective through the 1960s and into the early 1970s. However, as uninformed, environmental extremism prevailed by manipulation in the legal system in the late 1970s and 1980s, we have lost all that our country had gained by the creation of the competitive Civil Service idea plus all gains fostered specifically by SRM!

Regarding SRM activities, I don't recall that I served as an officer of the PNW Section, but I did serve on some committees. At the national level, I served 1 term on the National Board of Directors; I don't recall which years. I also served as Chairman of the Rangeland Resources Education Council, the Committee on International Relations, and the Summer Camp Committee for the PNW Section; maybe others, but I don't remember.
Somehow I feel that our toughest problems are ahead of us, and I'm deeply concerned by some of the trends I see within the renewable natural resource agencies and in education. When an agency hires people to do rangeland resource evaluation and documentation who literally don't know one plant from another, something is drastically, yes, unbelievably, WRONG!

When Condition and Trend data sheets repeatedly show multiple "Unknowns" per data sheet, including the most frequent/prominent species, and the supervisor admits he hasn't checked the year-old data sheets, you can decide for yourself where the problem lies. Situation confirmed. Why this unfortunate turn of events? Why have we lost ground in such an important area as professional standards?

One fundamental reason is that some SRM members feel, probably rightly or through their own interpretation of related events, which they are not free to become involved in a discussion or vote if the outcome is not in line with agency policy. To the extent that this does exist, it is most unfortunate for SRM and for the persons involved. My own interpretation would be that, if an agency, subtly or intentionally, encouraged the attitude/feeling, it could constitute an insidious denial of the right of free speech. If, on the other hand, a person is representing an organization that, in and of itself, is a member of SRM, then that agency's representative is duty-bound to present or clarify the policies and views of his or her member agency.

I have always held that any member of a professional organization like ours should be free to express a personal opinion on any relevant topic whether it fits the current mold or not. Progress is never created by conformity. Blind conformity produces lethargy and suffocation. Progress results from divergences of thinking, imagination and new ideas, perceptions that are different, divergent, or even in direct opposition. Progress arises from the common ground, the resolution of difference, and the amalgamation of the good or innovative in each contributor's thinking. Here is a case in point that needs to be told now that many years have passed.

When I was on the Board of Directors, we were considering an important issue (I don't remember specifically what it was). There was significant divergence of opinion, but all discussions were a model of civility. We were seeking a common ground where all could agree or live with the consequences. We finally got there, and a vote was called. One of our Directors said, "I'm sorry, I can't vote on that issue, it is contrary to my Agency's policy." More than I were shocked that a person who had been voted into an important office by his peers with the assumption that he would bring his best professional judgment as an individual member to bear on the matter of guiding the Society would feel pressed to make such a statement. Why didn't he just say, "I abstain"? Think about it.

I went home and wrote a short, philosophical article on the subject, "The Hats We Wear." It mentioned no names or agencies nor referenced any specific topic. I made the theme 
point that when one joins a Professional Association as an individual, he or she should have all rights of independent, personal expression and is expected to perform as a peer on equal footing. Then I discussed some the potential impacts of the Hat We Individually Wear as members and especially as Officers of the Society. My thrust was that an individual as a member of a nonprofit, professional organization should be completely free to speak as an individual on organization matters, especially when in elective office.

I submitted the article for publication by SRM. It was summarily turned down with the comment, "Not suitable," and without suggestions for revision or modification that would make it suitable. I still have the article as a memento of a sad day in the history of SRM.

I see SRM at a critical crossroad mostly in matters of professional standards and fundamental science requirements. The Society has as much obligation, possibly more, to be involved in these matters and in Civil Service certification when that process adversely affects personnel qualification and the quality of performance and accomplishment in matters relating to Rangeland Resources research, extension, analysis and monitoring, and management practices. We can't dictate to the employers, but we can negotiate. Are we?

The Society's leadership and members can choose to aggressively reassert leadership and influence from a new position and platform based on collective mastery of fundamental plant taxonomy and ecology, earth, zoological, and human sciences that are the foundations of principle and practice for our profession. This is more than a 1-person task, but SRM can function better as the catalyst that refocuses the profession on mastered fundamentals. Failing in this is to accept oblivion in the 21st century with Human Society and Mother Earth as the losers while leadership remains with superficially educated and trained "Environmental Managers" and with management decisions remaining in the hands of the courts.

The best thought I can leave for future generations is that a science-based career in the judicious use and scientifically sound management of all renewable natural resources will become increasingly important and be needed as long as there are people and animals on earth. Innovation, ingenuity, and your cognitive skills-not conventional practicewill rule.

Superficial training and any old course in ecology doesn't cut it. Don't fall for the line, "In today's complexity, we need generalists who can put it all together." If you don't know the pieces and their characteristics, you can't put the puzzle together.

Make sure, at each step in your education, that you can say, "Here, in this area/discipline I have the potential of an expert by virtue of my fundamental understanding of related science and my skills and ability." With this core, you can generalize your education to your heart's content. Well-chosen generalization can improve your communication skills: step 1 being "Listen with Respect."
It is your responsibility to become adequately educated, trained, and experienced in the basic sciences upon which your profession is based, ie, plant taxonomy and phytosociology coupled with soil morphology, genesis, and classification; vegetation-soil-landform relationships; and how to translate this information into a fundamental ecosystems context that accurately characterizes each landscape.

Learn to read landscapes in terms of homogeneous vegetation-soil-landform ecosystems. If you can't do this, you are not qualified to lay out Condition and Trend transects or to take meaningful data on vegetation change, the key to your success or failure as a resource manager.

Prepare yourself well, and don't spring the trap by assuming that your education ever stops. My experience has convinced me that the following quote from Albert Einstein is as appropriate today as when he stated, "We cannot solve our problems with the same level of thinking that created them."

Back in the 1950s and 1960s, I used to tell my students, "When on the job, if you don't do a excellent job of informing your general public about what, how, and why you do what you do in renewable natural resources use and management, you will see the day when your management decisions are made for you in the Court of Law." I didn't think it would come so quickly.

Now that it is here and thoroughly entrenched, you are doubly obligated to be highly professional, impeccably accurate, and scientifically defensible in everything you do. Get on the speaking circuit. Take the offensive with information, irrefutable scientific fact, plus careful explanations of How and Why you do What you do, and the consequences of alternative courses.

From this initiative, build your support in a contingent of people willing or convinced to listen. Don't overlook school kids, 4th grade and up, and their teachers. They are a viable audience well worth the investment. Teachers lack materials, scientific facts, and an understanding of ecological principles and processes to teach about what environment really means and especially the concept of "renewable natural resources"the power of recovery in native vegetations and the folly of trading renewable resources for steel studs.

Don't buy into the radical environmentalists' and their lawyers' game by saying, "I don't have time. I have to prepare for the next court case." That's right where they want you to be and to stay. Remember that the strategy of the opposition in this white or black (not ethnic) arena is to build emotion not reason, to discredit, to obscure and confuse, cloud the facts, and capitalize on half-truth, which are even wrong when it has the "right" impact.

To all the young professionals in renewable natural resources use, management, and rational sustainabilityMay your career be enjoyable, challenging, and rewarding in satisfaction. May the Earth and its resources, its people, societies, and economies be healthier because of the decisions each of you make in your personal Journey of Discovery and Service - the World a better place because you walked by. 
SRM Charter Member-Gene F. Payne

Editor's Note: Dr Gene Payne, 127 N. 25th Ave., Bozeman, MT 59718-2603, was interviewed by Tracy Brewer in December 2002. This is an abstract from the lengthy and comprehensive interview. Dr Payne is a retired Professor of Range Management from Montana State University.

While at the University of Idaho in 1943 doing my MS thesis, there was talk of forming some kind of professional range management organization. This was, of course, in World War II, and there were few MS candidates. My first knowledge about what was to become the Society was at a meeting in Moscow, Idaho, in spring 1943, when perhaps 30-40 people came together who were interested in the establishment of some kind of professional organization. They met at the School of Forestry at the University of Idaho. My major professor, Dr Vernon Young, insisted that I take some time from my thesis writing and do a little research on rangelands in the southeast. He gave the group a job on the need for this society nationwide, and so my interest in it started at that early stage. The group that met at Moscow was essentially the same group that finally established the Society in the meeting in Salt Lake City, Utah. I was unable to attend that meeting, but since then, I have been closely involved in committees up until my retirement in 1979. That is a period of some 32 years.

Activities were varied in those early days. We met primarily in western locations, and the meetings were generally pretty much the format used in meetings now, ie, technical papers, and the people who were attending the meetings were primarily university and state and federal personnel. That didn't last very long as the primary focus because there were a number of ranchers who got interested in the Society. They came in with a strong influence in looking at the science of range management, as it would apply to private operators' operations.

Sections weren't formed immediately. But, within 2 annual meetings the idea of Sections was pretty well established. They first were on an informal basis but soon were formalized with their own officers. In Montana, we included North Dakota, South Dakota, and Wyoming, knowing that few people in the Society who came from that area. There were a good many meetings about what Sections should form and what the boundaries should be. In the Montana situation, we had several very active and influential ranchers who had their input, and the big question was "Should Sections be by state or should they be by natural rangelands boundaries?" It ended up very shortly as a tug-of-war between what we might call the mountain range managers and the plains range managers. Two ranchers particularly, one was Dan Fulton, were very influential in finally pushed the idea of biosections, in essence, and so a group got together and set a line of western and eastern Montana as a boundary between the Northern Great Plains (NGP) Section and the International Mountain Section. Wyoming chose to stay as its own group. The membership of the Northern Great
Plains Section included North Dakota; South Dakota; Montana, east of the Rockies; and a little later, the Canadian group from the plains of Alberta, Saskatchewan, and Manitoba. In that group, we had a large area that did encompass pretty well the northern Great Plains bio-area.

The Section problem was an interesting one. The ranchers who were so influential were from eastern Montana, and their approach was that western Montana had its school at University of Montana at Missoula (school of forestry that had a range program), and Montana State University (MSU), although west of the boundary that had been set, was the best representative of the plains agriculture. They pushed very hard in getting MSU to establish a student group attached to the NGP Section, although we were west of that boundary. I was quite in favor of it, although it was an odd situation. Also, most of the students in those very early days of 1947, 1948, 1949 , and into the 1950s came from the plains area east of the boundary that had been set. So, I was quite in agreement with those ranchers and where we were for a good many years. The student group here was officially in the NGP Section. Over time, that kind of fizzled out as an official connection with the advent of many students who came from outside of the NGP Section. Apparently, the direction has been to let students be in whatever Section they wanted to be in. By and large, the staff just assumed as staff changes came along, with the exception of me, that because we were west of the boundary, they were International Mountain members. For many years, some of the faculty were International Mountain Section members and some were NGP Section members. It was a matter of geography. The artificial boundary was through Stillwater and Sweetgrass counties, which put us not too far from the boundary. I don't know by now what the official relationships are.

My expectations of the ASRM early on were that it was a place to prevent us from becoming too provincial in developing curricula and attitudes that would leave an institution with a too restricted view of the science, for one thing. And, for another, I thought it was extremely valuable if we could get students involved, which did happen. That led to development of teams of one sort or another that would go to the national/international meetings.

We talked a great deal about advances in range science, and this was extremely important in avoiding provincialism that can deaden curricula. The other important thing was how involved the Society should be in political questions related to the management of rangelands. This was touchy because the membership in general wanted or seemed to want to use the Society primarily as the means of getting a broader horizon than that of the agencies that they were working in or the ranching industry as such. So, in general, the attitude was, don't get involved in politics, at least, not in any significant way.

I started out at the University of Montana at Missoula in the mid-1930s, and times were pretty tough. I was in and out of school and that depended on the kind of summer jobs and 
that sort of thing. I started out in Forestry and was somewhat intrigued with the botanical side. I had a couple of quarters of work as a major in Botany and then moved back into the Forestry/Range Management program there. By rather peculiar circumstances, I decided to make the move to the University of Idaho to finish up my BS in Forestry with a major in Range Management. I graduated in the spring of 1941 and then went to work for the Soil Conservation Service until the fall of 1941 when the war disturbed everything. At that time, I was able to take a graduate assistantship at University of Idaho and completed that in 1943. I spent a little time at the Jornada range station in New Mexico. Rather than be drafted, I volunteered in an engineering unit in the US Army. As any WWII veteran would tell you, you could volunteer for almost anything and be sure you would do it. So, I ended up after basic training in an administrative position, clerical-type stuff, and stayed in that for the remainder of the war, most of it in England.

After the war, I came back to the SCS in eastern Washington before finally coming to the job in Bozeman, Montana, at MSU. I arrived here in the fall of 1947. I was in the program that Dr Harold Heady, a very influential person in the Society, had started near the beginning of the war and finally had to abandon it as a major source of study because there simply were not the students for the subject. At the end of the war, he was able to turn his attention to development of the curriculum. Then, he went off to Texas A\&M and then the University of California. Dr Chuck Poulton, also one of the early pioneers in the Society and outspoken proponent of Society development, was here for a year. He further developed the curriculum, so I had a fairly good base from which to work. (Gene is modest. He earned a $P h D$ in Range Management in 1957 from Texas A\&M University with major professor Dr Vernon Young. Ed.)

I was involved in several committees in SRM but especially at the Section level. In the early days, the Secretary of the Society was a volunteer essentially from the membership. He was not paid anything except for actual expenses for key records, paper expenses, etc. The Secretary was totally voluntary, although often pressured to take the job. The year that Dan Fulton, a rancher from eastern Montana, was President of the Society, he appeared on campus and talked to the head of Animal and Range Science and the Dean about the importance of my being Secretary while he was President. So, I spent a year in the Secretary position. Then there were several committees of one sort or another of which I was a member. Eventually, I was deeply involved in the formation of the committee on range management education. I don't remember the exact name of the committee, but essentially it was getting the range teaching staffs together as a committee to talk about curriculum content and student development, things of that sort, which finally evolved into the Range Management Education Council. I was deeply involved with the NGP Section and committees and was President of the Section twice.
I have been concerned about the Society and the problem of membership. I'm not in a position to attend all the national meetings after my retirement from the university, but I have been trying to keep up with problems that are expressed in the Journal and particularly in Rangelands and any other information I can get. The Society has a drop in membership that concerns me. I think it was a complex thing. One of the factors was the tendency of agencies that normally had taken range management students on their staffs to look more to students from schools that teach a less well-defined curriculum in general, ie, conservation. I believe this agency perspective considerably eroded the need for professional range people. This began to have an effect on the Society. There were other things also that were involved, quite a number of them.

As time went on, more and more, the SRM seemed to be looked upon as a Society for private rangeland management. The interesting thing was that, with the exception of a few very deeply interested ranchers, the Society still was depending on the various governmental agencies as a source of membership.

I think that perhaps the master philosopher on the whole problem of membership and the direction of the Society was Dr Thad Box from Utah State University. One of the things I think we ought to be proud of as a Society is that a number of people were concerned about the problem and were looking at the whole question of membership and how to get members interested in the management of rangelands and what was really meant by the term "rangelands." All of these sorts of things are finally coming to the fore. I am encouraged by the time that has been spent looking at the functions of the Society. The philosophical problems that arise in a Society like ours include trying to set some boundaries from within which the Society could contribute most. I think that is being worked through in a very commendable fashion.

The series of articles by Dr Box has outlined the problems that need to be faced and the attitudes that need to be evaluated. For example, there is a real question as to whether the Society has been wrong in maintaining the man on a horse as the dominant symbol for the Society. That may seem rather a picky thing, but symbols like this very often categorize a Society like ours. There are any number of people who still look at our Society as a Society to help the ranchers and to have little application elsewhere. This, of course, is the problem. It is not a Society that is predominantly concerned with private property or public property but is interested in rangelands as part of the environment. Livestock, game, recreation, and water, all of these things are critical problems in our society. So, this broad viewpoint has to be brought out. It cannot be symbolized with a cowboy on a horse. We are far beyond this sort of thing today. But, it is hard to symbolize something like that. I am pleased that we are getting more wildlife people involved. More of the literature in rangeland publications deals with items other than ranchers' problems. I think the Society is coming into a new configuration when it comes to the membership and understanding of all the broad facets of rangelands management. 
One of the things that happened, as far as I personally was concerned, is that SRM provided an opportunity to see rangelands and rangelands management in a broad sense, a broad point of view. In other words, the tendency, I think, among people in rangelands related areas can, if they don't go to SRM meetings, if they don't go to technical sessions, tend to get a little bit too provincial in the curriculum in the schools, in the development of rangeland management technology. Probably the most important thing I got from SRM was broadening of experience and attitudes and thinking about the educational side of rangelands.

I'm biased, but I think rangelands educational programs in most of the schools have been broadening. As such, students are being developed who better understand the real complexities of rangelands management. Also, they are getting a much better point of view about all the peripheral things that are so important to our society. They need to learn more about ecology and economics and how this relates to the development and sustaining of our rangelands. The touchy problem of recreation and its influence on rangelands, and on decisions about various uses of rangelands, and in the various kinds of rangelands, eg, when rangelands are intimately tied into forestlands - the administration of such intermixtures is rather complex, as are the decisions about what has predominance in a lands situation involving water, recreation, and wildlife and how all these things tie together.

Finally, I hope members of the Society will continue to think about philosophical as well as practical questions.
What is the Society supposed to do? That should be an ongoing question. It was the question when the Society was established; it was a question that was a part of Society deliberations. It should be ongoing.

What is going on in SRM now in trying to decide on its responsibilities, its areas of concern, and how to improve its membership, which is very important in trying to spread the fundamental philosophy of rangelands management? All of these things are being examined rather closely. I am certainly hoping that the people in rangelands education are continuing to examine their curricula and to support and participate in the Range Science Education groups. They need to realize that all of the education today is spread out over a much wider view of what range management and rangeland science is and that they are more and more getting nontraditional students, ie, not from a ranch background. The approach to educational challenges now is different. One needs to recognize that the world is different today. I have not noticed as much in range management and range science literature about education as there was in earlier times. I'm trying to think about any articles recently that tackled the educational system and detailed the course content and curriculum. I am curious about how the Range Science Education Council is doing and what they are achieving in terms of better or more appropriate curricular/course additions/deletions. Are we really looking at the education side of SRM as thoroughly as schools should be doing? These are questions and concerns that I trust are being addressed. 